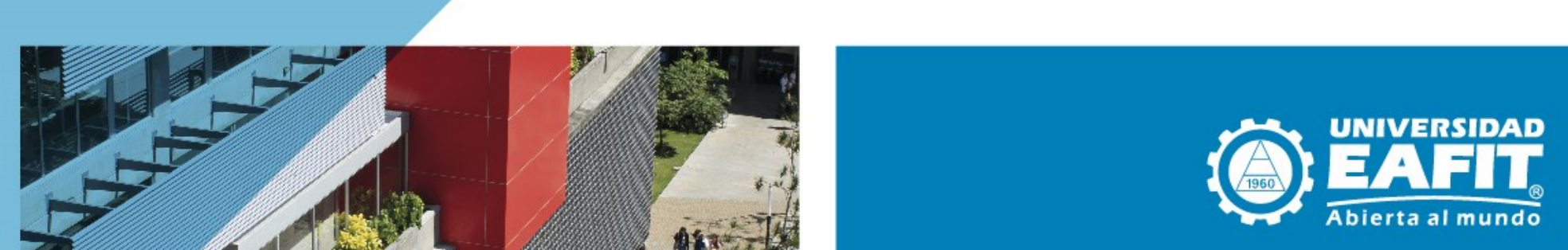

Escuela de Economía y Finanzas

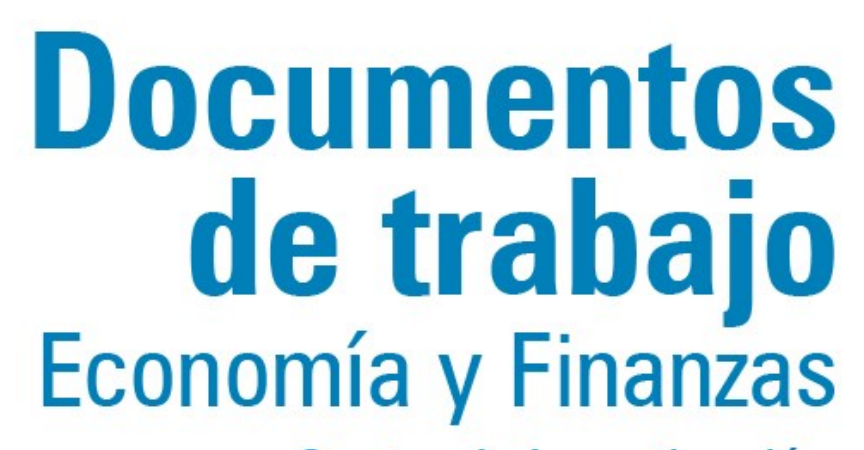

Centro de Investigación Económicas y Financieras

No. 16-13 Devaluation, competitiveness and new business forma2016 tion in emerging countries

Herrera-Echeverri, Hernán; Haar, Jerry; Arrieta Jiménez, Alexander; Araújo Zapata, Manuel

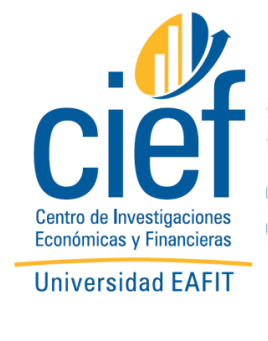




\title{
DEVALUATION, COMPETITIVENESS AND NEW BUSINESS FORMATION IN EMERGING COUNTRIES
}

\author{
HERNÁN HERRERA-ECHEVERRI \\ School of Economics and Finance \\ Universidad EAFIT, Cra. $49 \mathrm{~N}^{\circ} 7$ sur 50 \\ Medellín, Colombia \\ hherrer2@eafit.edu.co \\ JERRY HAAR \\ College of Business, \\ Florida International University \\ 1200 SW 8th Street, CBC201 \\ Miami, FL 33199, United States \\ Haarj@fiu.edu
}

ALEXANDER ARRIETA JIMÉNEZ

School of Economics and Finance

Universidad EAFIT, Cra. $49 \mathrm{~N}^{\circ} 7$ sur 50

Medellín, Colombia

aarrieta@eafit.edu.co

MANUEL ARAÚJO ZAPATA

Economics and Finance School

Universidad EAFIT, Cra. $49 \mathrm{~N}^{\circ} 7$ sur 50

Medellín, Colombia

maraujo1@eafit.edu.co

In September 2010, Brazil's Finance Minister, Guido Mantega, used the term "currency war" with reference to monetary policies implemented by different countries to generate an artificial devaluation of their currency and achieve a cheaper, more competitive domestic economy that may be attractive to foreign investors. Similar cases have been documented since the 1930s Great Depression, when several countries abandoned the gold standard as backing for their currencies. More recently, a large-scale asset purchase by Japan's Central Bank in 2013 was singled out as a strategy aimed at generating devaluation of the yen. This research uses statistics of new business formation density reported by Doing Business for 30 emerging countries in the period 2004-2011 to evaluate the impact of devaluation measured by the behavior of the real effective exchange rate (REER) on the rate of new business formation (NBF). It is determined how variables associated with competitiveness affect the relationship between devaluation and business formation. Results show that devaluation has a positive effect on NBF in the short term, which gets diluted in the long term. Countries with greater competitiveness have less dependence on devaluation to increase the number of businesses. 
Key words: New business formation, emerging countries, devaluation, competitiveness.

Classification codes: G18, G24, M13

\section{Introduction}

In September 2010, Brazil's Finance Minister, Guido Mantega, used the term "currency war" with reference to monetary policies implemented mainly by China, Japan, Thailand, South Korea, Colombia and other countries to generate an artificial devaluation ${ }^{1}$ of their currency in order to achieve a cheaper, more competitive domestic economy that may be attractive to foreign investors, as well as to be able to withstand the 2008 economic crisis (Eichgreen, 2013).

Similar cases have been documented since the Great Depression of the 1930s, when several countries abandoned the gold standard in order to depreciate their currencies so as to achieve a faster recovery (Eichengreen and Sachs, 1985; 1986), which triggered off the Tripartite Agreement of 1936 between United States, France and Great Britain, which other countries later joined in.

The variation of REER and its close relation to the economic growth experienced by emerging countries has been the subject matter of extended research in the economic literature for several years. Positive effects such as the Foreign Direct Investment (FDI) inflow incentive, lower labor costs and the improvement of investment efficiency are transmission mechanisms of the devaluation effect to the economy (Bhalla, 2012). However, the relationship between devaluation and business formation hasn't been studied so far. Academics have focused on the relationship between devaluation and FDI or FDI and business formation, without directly analyzing the relationship between devaluation and NBF.

The study of the phenomenon of entrepreneurship and the rise of new firms has captured the attention both of academics and government agencies in the last few decades. Its impact on economic growth and its close relation to factors that mark countries' competitiveness turn it into a central topic for policy definition by national and international authorities. As part of the strategies undertaken to encourage business formation, both developed and developing countries have fostered FDI on the basis of the existence of a "spillover" effect that adds more knowledge and demand for new products to local economies (Markusen and Venables, 1999; Barrios et al., 2005: Herrera-Echeverri et al., 2014). The results of Zhang (2006) and of Yao and Wei (2007) support a positive effect of FDI in the case of China, which since the

\footnotetext{
${ }^{1}$ We understand that devaluation (corresponds to price fixing) and depreciation (corresponds to natural variation of currency) are different, we are keen to examine whether the increase in exchange rate has implications on business formation regardless of its origins; we will use the term devaluation for its effect.
} 
1980s and 1990s has initiated a strategy of devaluation of the yuan to boost the growth of its economy in the following years.

Other factors that come into play in business formation have been mentioned, such as fiscal policy in terms of consumption by governments, credit access, technological developments and trade openness, which the literature has related to devaluation phenomena (Edwards, 1989; Reynolds et al., 2000; Black and Strahan, 2002; Choi and Phan, 2006; Takii, 2008); it is therefore worth wondering whether upon separating such effects devaluation continues having an impact on business formation. If such effect persists, is it short-term or long-term? And the final question is whether the relationship between business formation and devaluation is affected by the increase in competitiveness of the countries.

Answering those questions so as to contribute to public policy design that may stimulate entrepreneurship in emerging economies is the aim of this research paper. The panel data technique is employed on a sample of 30 emerging countries from 2004 to 2011 to analyze the following: the effect of devaluation on NFB and its period of duration; the variables that affect both devaluation and business formation; the residual value of devaluation on business formation after removing the effect of the variables that affect devaluation and business formation simultaneously; and, finally, how competitiveness variables affect the relationship between devaluation and business formation.

Research results reveal a positive relationship between devaluation and business formation rate in emerging countries; however, this effect is only short-term, as it gets diluted for periods longer than 2 years. Devaluation does not compensate for the importance of competitiveness in promoting business formation in emerging economies. The devaluation effect loses magnitude and significance against very low competitiveness levels in terms of credit supply for the private sector and institutional quality.

These findings show the importance of maintaining a good balance between short- and longterm strategies to boost the dynamics of business formation in developing economies. Natural or artificial devaluation can contribute short-term growth advantages, but public policy should seek to improve competitiveness to achieve higher levels of entrepreneurship for the country in the long term.

In the following section the main papers, both theoretical and empirical ones, related to devaluation and business formation are reviewed. In section 3, the premises of the models, the hypotheses raised, the methodology and the data used to test those hypotheses are presented. The results and their analyses are detailed in section 4, while in section 5 the conclusions, the discussion of main findings, the limitations encountered and some proposals for future research are presented. 


\section{Devaluation and business formation in different competitive contexts}

Although a direct relationship is not established, the available literature is focused on mentioning how devaluation can dynamize some aspects of the economy that influence business formation, such as lower labor costs, reallocation of production factors and FDI increases. Theoretical approaches and empirical outcomes indicate that devaluation generates a reduction in labor costs in comparative terms. As labor costs are reduced, profit margins are increased and investment, savings and capital accumulation are fostered and these conditions favor NBF. (Levy-Yeyati and Sturzenegger, 2007; Bhalla, 2007 and Rodrik, 2008).

Theory also holds that devaluation phenomena influence productivity improvement by the reallocation of production factors (capital and labor force) from less profitable sectors to more profitable ones (Gala, 2007; Mbaye, 2012) and this can generate a positive effect on business formation. The productivity increase of production factors promote investment development and, in turn, NBF. This idea has been supported empirically by several papers, for example Mbaye (2012), using data from 72 countries between 1970 and 2008, found that an increase in devaluation favors growth through improvement in productivity.

Another impact channel of devaluation on business formation is FDI. Both the theory of imperfect capital markets and the theory of relative labor costs point out that an increase in REER goes hand in hand with increases in FDI inflows. According to Froot and Stein (1991), information asymmetry in capital markets causes foreign sources of funding to be more costly than domestic ones, which encourages the search for lower capital costs through asset acquisition in economies with devalued currencies. Likewise, the relative labor costs theory predicts that a depreciation of the real exchange rate increases FDI inflows attracted by lower labor costs (Kosteletou and Liargovas, 2000).

Working papers by Markusen and Venables (1999) and Barrios et al. (2005) put forward analytical models regarding the positive impact of FDI on the rise of new businesses. A "spillover" effect comes about because FDI increases the demand for intermediate products and services as well as the supply of capital, technology and new knowledge.

The results of empirical models reported by Zhang (2006), Yao and Wei (2007) confirm the existence of a positive FDI effect on the growth of the Chinese economy from the beginning of the 1980s and 1990s, as a result of the positive interaction between FDI and human capital that speeds up growth, and the stimulus to technological progress generated by FDI. Burke et al. (2007), Barbosa and Eiriz (2007) confirm an overall predominance of the "spillover" 
effect over the "crowd-out" effect in United Kingdom and Portugal. Likewise, Xu and Chang (2008) report the existence of the "spillover" and "crowd-out" effects in China nationwide and regionwide respectively. Ayyagari and Kosová (2010) also contribute evidence of the positive effect of FDI on entrepreneurship at both inter-sectorial and intra-sectorial levels in the Czech Republic.

Despite the positive effect that REER devaluation is expected to have on investment, it has been empirically shown that its effect on the growth of the economies is only short-term, and on the contrary it doesn't turn out to be significant in the long term. The Bahmani-Oskooee research (1998) in 17 developing countries confirms the inexistence of a long-term devaluation effect on their production in the period 1973-1988. Karadeloglou et al. (2001) also reveal the absence of a long-term devaluation effect on Bulgaria's economy.

Another element to consider in the analysis of the relationship between REER and NBF is the existence of phenomena that affect them jointly. Reynolds et al. (1999, 2000), Edwards (1988), Elbadawi (1994) and Montiel (1999) identify the factors affecting the real exchange rate and new business formation simultaneously. Financial resources, institutional quality, government policies, technological transfer and trade openness, together with government consumption expenditure and capital inflows form part of the factors called "economic fundamentals", whose behavior may generate revaluation or devaluation while affecting entrepreneurship levels.

The theoretical approaches discussed so far indicate that devaluation might generate some conditions that can promote investment in the short term; however, it is not clear whether such effects are transferred to the increase in new businesses and how lasting those effects can turn out to be. There is also evidence of the existence of variables that may simultaneously affect NBF and devaluation. It is necessary to establish empirically whether devaluation may have a residual significance on NBF after isolating those effects. These considerations will be taken into account in the methodological development of the econometric models.

The second focus of interest in this paper lies in establishing the benefits of a devaluation policy for business formation in countries with different competitiveness conditions. The interrelation between competitiveness, devaluation and business formation has been studied by some authors; for example Drine and Rault (2003) and Joyce and Kamas (2010) mention that REER appreciation in the long term is explained by the increase in exchange terms, increase in GDP per capita, capital inflows, but also by the countries' improvement in productivity. 
Likewise, an increase in a country's competitiveness has positive effects on the increase in FDI, international trade and domestic demand. Several research studies in the field of entrepreneurship contribute evidence of the benefits of these phenomena on business formation (Clercq, 2008; Ayyagari y Kosová, 2010 and Misra et al., 2012). Apart from market factors, other institutional factors are evidence of the competitiveness increase of a country and at the same time favor new business formation. A clear example is the decrease in corruption levels, the decrease in costs and in the number of formalities to register new firms (Koveos et al., 2011 and Munemo, 2012).

In view of public policy developers' confidence in using devaluation to promote the growth of the domestic industry (to name but a few, governments of China, Japan, Thailand, South Korea and Colombia have resorted to devaluation), it is necessary not only to validate empirically whether devaluation has had a significant impact on new business formation but also to establish how this impact behaves when the country has worked on improving the competitiveness of its economy.

\section{Empirical modeling}

The objective is to model the effect of devaluation on new business formation in emerging countries through the panel data technique, establish if such effect is long-lasting and whether it is preserved after controlling the variables that, according to the literature, may simultaneously affect the behavior of REER and NBF. The methodological strategy is the following: a first model shows NBF in terms of REER, the complete specification of the model is described in the following way:

$$
L N N B F_{i t}=\alpha_{i}+\beta_{1} \operatorname{LNREER}_{i(t-l)}+\beta_{k}^{T} X_{i\left(t-j_{k}\right)}+\gamma_{i}+e_{i t}
$$

$L N N B F$ represents NBF density annual growth rate, i denotes countries, t denotes years, $j$ denotes lags in the variables, and $\gamma_{i}$ gathers the effect of temporal dummy variables on the model $^{2} . \alpha_{i}$ is a vector that contains the fixed effects per countries as confirmed by Hausman's (1978) and Breusch and Pagan's (1980) ${ }^{3}$ tests. LNREER captures annual REER movements, while $X$ constitutes a vector with control variables identified in the economic literature as NBF determinants. In order to verify whether the devaluation effect on NBF remains in the long term, the variable $L N R E E R$ is evaluated in lags greater than 2 years as shown below:

$$
\operatorname{LNNBF}_{i t}=\alpha_{\mathrm{i}}+\beta_{1} \operatorname{LNREER}_{\mathrm{i}(\mathrm{t}-\mathrm{l}>2)}+\beta_{\mathrm{k}}^{\mathrm{T}} \mathrm{X}_{\mathrm{i}\left(\mathrm{t}-\mathrm{j}_{\mathrm{k}}\right)}+\gamma_{\mathrm{i}}+\mathrm{e}_{\mathrm{it}}
$$

\footnotetext{
${ }^{2}$ The tests carried out in the Stata software revealed the effect of a dummy variable in the year 2009.

${ }^{3}$ The presence of fixed effects in the model coincides with the findings of Sutaria and Hicks (2004).
} 
In order to verify the behavior of REER in terms of the variables simultaneously affecting NBF, Edwards' (1988, 1989) and Hussain's (2011) approaches are followed. The authors agree on stating that REER movements in emerging economies are determined by short- and long-term factors, both domestic and foreign, that affect the relative price between tradable and non-tradable goods:

$$
\text { LNREER }_{\mathrm{it}}=\varphi_{\mathrm{i}}+\phi_{1} \psi_{\mathrm{i}\left(\mathrm{t}-n_{k}\right)}+\lambda_{\mathrm{t}}+\mu_{\mathrm{it}}
$$

Where LNREER represents annual REER growth, i denotes countries, $\mathrm{t}$ denotes years, $k=$ $1,2,3, \ldots 6, n$ represents the lags in the variables and $\varphi_{\mathrm{i}}$ is a vector that contains the fixed effects per countries as revealed by Hausman's (1978) and Breusch and Pagan's (1980) ${ }^{4}$ tests. $\lambda$ is a dummy variable of temporal effects ${ }^{5}$, whereas $\psi$ is the vector composed of control variables.

From the models above, the common variables are established that show significance to explain NBF and REER. The methodology used by Gwartney et al. (2004) is followed, substituting REER for the residual after extracting the effects of the variables that prove significant in both models. The econometric approach for this solution is the following:

$$
L N N B F_{i t}=\alpha_{i}+\pi_{1} L N R E E R_{i(t-1)}^{*}+\pi_{k}^{T} X_{i\left(t-j_{k}\right)}+\gamma_{t}+\varepsilon_{i t}
$$

With

$$
L N R E E R_{i t}^{*}=L N R E E R_{i t}-\phi_{k}^{T} Z_{i\left(t-n_{k}\right)}
$$

Where $L N R E E R^{*}$ is the residuals that result from extracting the effect of the variables causing both NBF and REER, which are represented in the vector $Z$. Please note that in the equation 3.5 common variables maintain the coefficients and lags defined in equation 3.3 and that $K<=3$. With the results of this model, it is sought to establish whether devaluation maintains its positive effect on NBF, even after subtracting the effect the common variables cause to REER and NBF.

Three final models are used to check whether the competitiveness level (measured specifically in terms of credit supply and institutional quality) of the countries significantly influences the devaluation effect on NBF. The effect of REER on NBF is evaluated when credit supply and institutional quality are below their mean in the country sample. The econometric approach is the following:

\footnotetext{
${ }^{4}$ Tests carried out in the Stata software confirm the presence of fixed effects in the model.

${ }^{5}$ The tests carried out in the Stata software revealed the effect of dummy variables in the years 2010 and 2011.
} 


$$
\begin{gathered}
\operatorname{LNNBF}_{i t}=\alpha_{i}+\pi_{1} \operatorname{LNREER}_{i(t-1)}^{*}+\pi_{2} \operatorname{LNCI}_{i\left(t-j_{2}\right)}^{\leq Q 2}+\pi_{k}^{T} X_{i\left(t-j_{k}\right)}^{*}+\gamma_{t}+\varepsilon_{i t} \\
\operatorname{LNNBF}_{i t}=\alpha_{i}+\pi_{1} \operatorname{LNREER}_{i(t-1)}^{*}+\pi_{2} \operatorname{LNDCPS}_{i\left(t-j_{2}\right)}^{\leq Q 2}+\pi_{k}^{T} X_{i\left(t-j_{k}\right)}^{*}+\gamma_{t}+\varepsilon_{i t} \\
\begin{aligned}
L N N B F_{i t}= & \alpha_{i}+\pi_{1} L N R E E R_{i(t-1)}^{*}+\pi_{2} \operatorname{LNDCPS}_{i\left(t-j_{2}\right)}^{\leq Q 2}+\pi_{3} L N C I_{i\left(t-j_{3}\right)}^{\leq Q 2}+\pi_{k}^{T} X_{i\left(t-j_{k}\right)}^{*}+\gamma_{t} \\
& +\varepsilon_{i t}
\end{aligned}
\end{gathered}
$$

In each of the equations, the variables $L N D C P S^{\leq Q 2}$ and $L N C I^{\leq Q 2}$ represent the quartiles one and two of domestic credit supply to the private sector as a percentage of GDP and institutional quality, whereas the vector $X$ contains the control variables. The results of these models will make it possible to determine whether the devaluation impact on NBF in developing economies is only significant when countries reach better competitiveness levels in terms of financial resource supply to entrepreneurs and the quality of their public institutions.

\section{Description of variables}

The dependent variable (NBF) is measured with the new firm formation density, defined as the number of new firms registered per 1,000 economically active people reported by Doing Business for 30 emerging countries in the period 2004-2011 (Klapper et al., 2007; Klapper and Love, 2010; Munemo, 2012; Herrera et al., 2014). Unlike other entrepreneurship measures such as those of Global Entrepreneurship Monitor (GEM) that reflect the informality of the economies by capturing individuals' intention of starting a business, the new firm formation density shows greater adjustment and consistency in measuring NBF across countries by taking into account only the number of firms that become part of the formal economy annually; however, it has the limitation of not considering other forms of organization of entrepreneurial activity.

Some control variables are used to verify the robustness of the results. First, government expenditure (LNGCE). Greater government spending on acquiring consumer goods, which later reach households through social assistance programs or subsidies, can have a "crowdout" effect on private consumption and may become a barrier to the entry of new firms. In order to measure this effect, recent research studies have used government final consumption expenditure as a percentage of GDP (Aidis, 2012).

NBF is expected to be influenced by the behavior of demand in the markets (Evans and Jovanovic, 1989). The greater demand for goods and services opens up opportunities for the entry of new firms in expansion times (Reynolds et al., 1999). GDP per capita (LNGDPP) has 
been widely used as proxy for demand behavior (Spencer and Gómez, 2004). Since some empirical studies suggest the existence of a shelter effect, whereby individuals undertake new businesses as a way of generating income in a context of increased unemployment (Reynolds et al., 2000), the unemployment rate is also included (LNUE).

Flexibility in the procedures required for new business formation is an institutional factor of great impact on NBF dynamics. Bruton et al. (2010) point out that the excess of procedures required for registering a business (LNSPRB) is a factor that can discourage the rise of new companies. Research studies in emerging countries reveal a negative association between the increase in the number of procedures and the entry rate of new firms (Klapper et al., 2007; Bruhn, 2011).

The variables used to measure specific aspects of the competitiveness level of an economy are described and justified below. First, there's the availability of credit for the private sector as a percentage of GDP (LNDCPS), since availability of credit access for entrepreneurs constitutes a decisive factor for the leverage of nascent firms (Reynolds et al., 1999, 2000). A large number of empirical studies contribute evidence for the positive relationship between credit supply and entrepreneurship rate (Black and Strahan, 2002; Klapper et al., 2007; Robb and Robinson, 2012).

The degree of business transparency is another institutional factor that affects the entry of new firms in emerging countries. Lower corruption levels generate greater confidence in individuals towards public institutions, reduce inefficiencies and eliminate additional costs for entrepreneurial activity that end up facilitating entrepreneurship. In order to assess the institutional quality of countries, the corruption index (LNCI) reported by Transparency International is used, which was also applied in recent research (Wu and Liang, 2012; Dreher and Gassebner, 2013). Empirically, authors such as Wei (2000) and Quéré et al. (2005) contribute evidence on the negative impact that corruption in public institutions has on investment in developing countries. High corruption levels deprive countries of competitiveness and turn them less attractive for investors.

It is known that the competitiveness level reached by countries positively influences the NBF rate. The World Economic Forum, from the 12 pillars that make up the global competitiveness index, highlights the importance that government transparency has to avoid extra costs for companies and to facilitate economic development, as well as the credit access facility for entrepreneurs that allows them to leverage their investment projects (Schwab, 2011, 2012). The Global Entrepreneurship Monitor (2011) in its conceptual model also remarks how the funding of ventures and the strength of institutions accompanied by public policy help in promoting entrepreneurial activity. 
The control variables for the devaluation model are mentioned below. Technological progress: According to the productivity differential theory (Balassa, 1964 and Samuelson, 1964), a productivity increase in tradable sectors boosts an increase in salaries in the overall economy, which in turn generates a price increase in non-tradable goods and, as a result, a decrease in REER. Several studies have considered the growth of GDP per capita (LNGDPP) as an appropriate proxy that gathers the effect of productivity derived from technological progress on REER (Drine and Rault, 2003; Kim and Korhonen, 2005).

Government consumption: According to the dynamic model put forward by Edwards (1988), the increase in government consumption of non-tradable goods has the effect of appreciating the real exchange rate in the short term. In order to measure this variable, government final consumption expenditure as a percentage of GDP (LNGCE) is used. Authors like Hussain (2011) confirm appreciation of REER in six emerging countries of the Southeast Asia derived from a greater share in government final expenditure on GDP.

Domestic credit: An expansive policy in terms of credit growth can result in a greater demand for tradable goods, non-tradable goods and financial assets (Edwards, 1989). It is expected that the increase in domestic credit can generate a greater demand for non-tradable goods thus devaluing REER. In order to measure the effect of domestic credit on REER, domestic credit to private sector (LNDCPS) as a percentage of GDP is used as a proxy variable; this variable has been employed in other studies for example in Daboh (2010).

The nominal exchange rate: Nominal exchange rate movements are expected to influence REER behavior positively in the short term. Several studies in emerging economies back up the positive effect of the nominal exchange rate (LNNEER) on REER (Edwards, 1988; Wahid and Shahbaz, 2009).

Openness degree of the economy: Following Elbadawi (1994), the sum of exports and imports of goods and services (LNTDE) as a percentage of GDP is used in this study to measure the openness degree of the economies. Greater openness of the emerging economies is expected to boost the non-tradable goods sector and to generate revaluation of REER.

Foreign direct investment inflows: FDI increments increase capital stock in local economies and generate a "spillover" effect of technological transfer that increases production and reduces prices of non-tradable goods, which in turn causes a devaluation of REER (Rehman et al., 2010). A higher FDI also translates itself into greater investment in tradable sectors, which generates a devaluation effect of the real exchange rate, as reported by Elbadawi (1994). Net foreign direct investment inflows (LNFDI) as a percentage of GDP are used to measure the FDI effect.

\section{Data and sample}


The information on NBF density analyzed in this study corresponds to 209 data reported by Doing Business in the period 2004-2011 regarding the number of firms with limited liability registered per every 1,000 people of working age (15 to 64 years old) for a sample of 30 emerging countries or frontier economies according to the Dow Jones and The Economist. The sample is composed by six Latin American countries, ten European countries, ten countries from the Asian continent and four African ones, as shown on Table 1. The sample heterogeneity makes it possible to obtain general results on the NBF pattern according to the specific characteristics of this type of economies, regardless of the geographical variable.

\section{$<$ Insert Table 1 here >}

The 300 data analyzed about the REER to evaluate its impact on NBF are obtained from databases made available by Bruegel for the period 2002-2011. The REER of each country is calculated against a currency basket of its trading partners (Darvas, 2012). Bruegel is an organization specialized in economic studies founded in 2004 thanks to the initiative of 12 governments of the European Union (EU), and its databases have also been used in recent research (Darvas, 2013). The additional information on the control variables used in the models was obtained from the World Bank database, as described in Appendix A. The difference in time periods of the two variables of interest is due to the limitations in data availability for NBF, which reduces the period under analysis. Descriptive statistics of the variables included in the study are found in Appendix C.

\section{Results}

The results are estimated with Panel-Corrected Standard Errors (PCSE) (Beck and Katz, 1995) in order to solve problems of heteroskedasticity, autocorrelation and potential crosscorrelation bias identified in the data. Despite argued limitations regarding the PCSE method associated with the difficulty of achieving a non-singular estimate of the covariance matrix when $\mathrm{T}<\mathrm{N}$ (Hoechle, 2007), empirical applications in this type of samples carried out by Friedland and Sanders (1985) and Scholz (1986) report efficient estimates in such cases.

The Hausman test (1978) reveals the presence of fixed effects, which matches the findings of Sutaria and Hicks (2004). The influence of non-observed characteristics in some years and countries on the results is controlled by dummy variables. The initial results of the NBF model are presented in Table 2 .

\section{<Insert Table 2 here>}


General statistical parameters show that both models prove to be well-defined, with Rsquared above $90 \%$ indicating that the exogenous variables used account for a great deal of NBF behavior. The significance of LNREER results in $t=2$, while LNGCE, LNDCPS and LNGDPP variables prove to be significant in $t=1$, which diminishes potential problems of endogeneity. Correlation matrix outputs contained in Appendix B rule out collinearity among the variables. The unit root tests in Appendix D reject the presence of unit roots and ensure stationarity.

The result of model 1 indicates that REER devaluation episodes generate a positive impact on NBF rate in emerging countries in the short term. In model 2, the devaluation effect is seen as not lasting over time and it disappears within a three-year window.

Another part of the results shows the positive impact of competitiveness variables such as LNCI and LNDCPS on NBF. LNCI with a coefficient of 0.906 generates the greatest positive impact on business formation, which reaffirms the claim that higher transparency levels favor entrepreneurial climate by creating confidence in business people, as remarked by other authors (Koveos et al., 2011 and Munemo, 2012). LNDCPS also has a positive impact on NBF; international evidence about the importance of credit availability facilitating entrepreneurship processes is confirmed. While the positive sign of LNGDPP reveals the effect of the increased demand for goods and services that encourages the entry of new firms as expected.

On the contrary, other control variables such as LNGCE and LNSPRB become barriers for NBF as pointed out by the theory. The negative sign of LNGCE confirms the "crowd-out" effect on private demand that limits opportunities for the entry of new firms, as remarked by Startz (1989). Likewise, the excess of procedures required for organizing new firms ends up discouraging entrepreneurship initiatives.

The results of the devaluation model confirm that LNGCE, LNDCPS and LNGDPP variables also determine REER behavior as shown in Table 3.

\section{$<$ Insert Table 3 here $>$}

The impact of LNGCE, LNNEER, LNTDE and FDI variables on REER behavior matches what is stated by the literature. The positive sign of LNGDPP contrasts with what the Balassa-Samuelson theory predicts, indicating that the increase in productivity in tradable sectors ends up decreasing the price of non-tradable goods instead of increasing it, thus devaluing REER. However, this theory has been structured based on evidence from developing countries, which does not necessarily match the behavior of emerging economies. For emerging countries evidence has been found that matches our results. 
For example, some Asian countries like China, Hong Kong, Malaysia and Singapore experienced fast economic growth before the financial crisis in 1997, but their currencies didn't become revalued, they even tended to get devalued. Such a seemingly contradictory phenomenon has been explained by $\mathrm{He}$ (2010) as a result of the increase in the variety of nontradable products on the markets which, together with the monopolistic effect that companies may have, tends to maintain or reduce the prices of these goods, thus generating REER devaluation.

In the fourth model, it can be observed how LNREER* residuals continue being significant for NBF, showing that despite the effect of LNGCE, LNDCPS and LNGDPP variables on REER devaluation generates additional effects on NBF. The sign and significance of the remaining control variables continue behaving properly, though their coefficients are slightly increased. The adjusted results are shown in the second column of Table 4.

\section{<Insert Table 4 here>}

Finally, it is also being tested how the devaluation effect varies when countries experience low competitiveness levels in LNCI and LNDCPS variables. The results of models five and six show that the devaluation impact diminishes in cases where the financial supply and institutional quality are low. Model seven, in turn, reveals how the devaluation effect loses significance when both variables present levels below their mean or quartile two. These findings support the conclusion that when institutional quality and credit supply to the private sector in emerging economies are low, devaluation loses its effect on NBF. Therefore, minimum competitiveness conditions are required in the economies for devaluation phenomena to influence business formation in emerging countries.

The negative sign in the $L N C I^{=Q 2}$ variable in models six and seven shows that the relationship between institutional quality and NBF does not follow a linear behavior; on the contrary, it charts a "U" course. This indicates that countries with high corruption levels or high institutional quality levels experience higher NBF rates, as pointed out by Wu and Liang (2012). Individuals make use of corruption through their influence on public power as a mechanism to gain advantages in resource appropriation and market access that benefit their businesses. As Dreher and Gassebner (2013) argue, when countries have inefficient administrative systems with overregulation (excess in formalities) or high capital requirements, corruption becomes an alternate mechanism that favors NBF. High corruption levels, the low quality of public goods and the State's weakness in guaranteeing law enforcement encourage informal entrepreneurship in the economies (Johnson et al., 1997). Low institutional quality is also reflected in a weak protection of property rights that triggers a predatory attitude in entrepreneurs, who seek to obtain higher returns seizing on technological developments created by others (González, 2005). 


\section{Conclusions}

Research results yield evidence regarding the initial question about the impact of devaluation on increased business formation in emerging countries. By means of a system of four models under a panel data structure for 30 emerging countries in the period 2004-2011, it is shown that REER devaluation stimulates NBF in the short term. However, this effect is not lasting over time and loses significance in a time horizon greater than two years, which suggests that other effects such as the increase in import costs brought about by devaluation can dilute its benefits over time (Krugman, 1978 and Edwards, 1986).

Yet, the devaluation impact on NBF ceases to exist when countries are not competitive. Results allow us to conclude that there are minimum levels in competitiveness factors from which devaluation may have significance on NBF. That is to say that, although devaluation generates opportunities for entrepreneurship in the economies, it is necessary to create conditions that can make it easy for new entrepreneurs to develop their business ideas, such as funding programs and improvement in public institutions which may guarantee property rights and free competition. The findings reported here show how devaluation ends up being an unsustainable mechanism to foster entrepreneurship in emerging countries. Any positive effect that may be derived from devaluation can only be maintained in the long term when countries manage to improve their competitiveness.

Finally, the development of this paper does not escape information limitations on variables of interest that might contribute greater robustness to its results. In particular, the use of a wider analysis period and the need to include other competitiveness variables such as quality in infrastructure, quality in education and tax rates, among others. However, the results reported, apart from being consistent with the related literature, throw light for future research on, for example, the assessment of the devaluation effect on net NBF at an inter- and intra-sectorial level, the knowledge of NBF patterns per regions or per development level of the countries, the knowledge of the devaluation impact on NBF in the presence of other variables such as the number of free trade treaties signed by countries or the determination of the threshold of competitiveness variables from which devaluation proves to be significant for NBF. 


\section{Appendix A. Variables used}

The variables included in the models were selected after a close review of the literature related to REER and NBF determinants.

\begin{tabular}{|c|c|c|c|c|c|}
\hline \multirow{2}{*}{ Variable } & \multirow{2}{*}{ Acronym } & \multirow{2}{*}{ Definition } & \multicolumn{2}{|c|}{ Expected effect } & \multirow{2}{*}{ Sources: } \\
\hline & & & NBF & REER & \\
\hline $\begin{array}{l}\text { New business } \\
\text { formation }\end{array}$ & NBF & $\begin{array}{l}\text { Number of limited liability firms registered } \\
\text { per } 1,000 \text { people of working age (15 to } 64 \\
\text { years old). }\end{array}$ & n.a. & n.a. & Doing Business \\
\hline $\begin{array}{l}\text { Real effective } \\
\text { exchange rate }\end{array}$ & REER & $\begin{array}{l}\text { Evolution of the real value of a currency } \\
\text { against a currency basket of its trading } \\
\text { partners. }\end{array}$ & + & n.a. & Bruegel \\
\hline $\begin{array}{l}\text { Government final } \\
\text { consumption } \\
\text { expenditure }\end{array}$ & GCE & \begin{tabular}{|l|} 
It includes all current expenditure for the \\
purchase of goods and services (including \\
salary payment). It also includes most defense \\
and security expenses. It is expressed as a \\
GDP percentage.
\end{tabular} & - & - & World Bank \\
\hline $\begin{array}{l}\text { Domestic credit to } \\
\text { private sector }\end{array}$ & DCPS & $\begin{array}{l}\text { Financial resources lent to the private sector } \\
\text { through loans, purchases of non-equity } \\
\text { securities, trade credits and other accounts } \\
\text { receivable that establish a claim for } \\
\text { repayment. It is expressed as a GDP } \\
\text { percentage. }\end{array}$ & + & + & World Bank \\
\hline GDP per capita & GDPP & $\begin{array}{l}\text { Gross domestic product per capita converted } \\
\text { to international dollars using purchasing } \\
\text { power parity rates. }\end{array}$ & + & - & World Bank \\
\hline Unemployment rate & UE & $\begin{array}{l}\text { Share of the labor force that is without work } \\
\text { but available for and seeking employment. }\end{array}$ & $+/-$ & n.a. & World Bank \\
\hline \begin{tabular}{|l|} 
Start-up procedures \\
required to register a \\
business
\end{tabular} & SPRB & $\begin{array}{l}\text { It includes permits and licenses necessary to } \\
\text { complete all inscriptions, verifications and } \\
\text { notifications to start operations. }\end{array}$ & - & n.a. & World Bank \\
\hline Institutional quality & CI & $\begin{array}{l}\text { Public sector corruption level perception, } \\
\text { rated from } 1 \text { to } 10 \text {. Where } 1 \text { is highly corrupt } \\
\text { and } 10 \text { is highly clean. }\end{array}$ & + & n.a. & $\begin{array}{l}\text { Transparency } \\
\text { International }\end{array}$ \\
\hline $\begin{array}{l}\text { Nominal effective } \\
\text { exchange rate }\end{array}$ & NEER & $\begin{array}{l}\text { Cost or relative price of a country's currency } \\
\text { in relation to a currency basket of its trading } \\
\text { partners. }\end{array}$ & n.a. & + & Bruegel \\
\hline $\begin{array}{l}\text { Foreign direct } \\
\text { investment net } \\
\text { inflows }\end{array}$ & FDI & $\begin{array}{l}\text { Net inflows of investment to acquire an } \\
\text { interest ( } 10 \text { per cent or more of voting stock) } \\
\text { in an enterprise operating in an economy other } \\
\text { than that of the investor. It is expressed as a } \\
\text { GDP percentage. }\end{array}$ & n.a. & + & World Bank \\
\hline $\begin{array}{l}\text { Openness degree of } \\
\text { the economy }\end{array}$ & TDE & $\begin{array}{l}\text { It is the sum of exports and imports of goods } \\
\text { and services as a share of GDP. }\end{array}$ & n.a. & - & World Bank \\
\hline
\end{tabular}




\section{Appendix B. Correlation matrix among variables}

The correlation matrix permits the identification of possible causality relations among variables when coefficients turn out to be high and are accompanied by marked significance. Based on this, no significant problems of multicollinearity are detected among the variables of the models.

\begin{tabular}{|c|c|c|c|c|c|c|c|c|c|c|c|}
\hline & LNNBF & LNREER & LNNEER & LNFDI & LNDCPS & LNSPRB & LNGCE & LNGDPP & LNUE & LNCI & LNTDE \\
\hline LNNBF & 1 & & & & & & & & & & \\
\hline \multirow[t]{2}{*}{ LNREER } & 0.081 & 1 & & & & & & & & & \\
\hline & 0.243 & & & & & & & & & & \\
\hline \multirow[t]{2}{*}{ LNNEER } & 0.227 & 0.582 & 1 & & & & & & & & \\
\hline & 0.001 & 0.000 & & & & & & & & & \\
\hline \multirow[t]{2}{*}{ LNFDI } & 0.496 & 0.041 & -0.057 & 1 & & & & & & & \\
\hline & 0.000 & 0.485 & 0.328 & & & & & & & & \\
\hline \multirow[t]{2}{*}{ LNDCPS } & 0.488 & 0.300 & 0.133 & 0.340 & 1 & & & & & & \\
\hline & 0.000 & 0.000 & 0.022 & 0.000 & & & & & & & \\
\hline \multirow[t]{2}{*}{ LNSPRB } & -0.603 & -0.307 & -0.172 & -0.395 & -0.482 & 1 & & & & & \\
\hline & 0.000 & 0.000 & 0.005 & 0.000 & 0.000 & & & & & & \\
\hline \multirow[t]{2}{*}{ LNGCE } & 0.285 & -0.001 & -0.039 & 0.086 & 0.205 & -0.121 & 1 & & & & \\
\hline & 0.000 & 0.983 & 0.507 & 0.140 & 0.000 & 0.048 & & & & & \\
\hline \multirow[t]{2}{*}{ LNGDPP } & 0.831 & 0.080 & -0.012 & 0.519 & 0.377 & -0.505 & 0.239 & 1 & & & \\
\hline & 0.000 & 0.165 & 0.832 & 0.000 & 0.000 & 0.000 & 0.000 & & & & \\
\hline \multirow[t]{2}{*}{ LNUE } & -0.007 & -0.078 & 0.014 & -0.165 & -0.173 & 0.104 & 0.386 & -0.117 & 1 & & \\
\hline & 0.925 & 0.224 & 0.832 & 0.010 & 0.007 & 0.127 & 0.000 & 0.068 & & & \\
\hline \multirow[t]{2}{*}{ LNCI } & 0.729 & 0.173 & 0.062 & 0.576 & 0.679 & -0.512 & 0.228 & 0.777 & -0.079 & 1 & \\
\hline & 0.000 & 0.003 & 0.288 & 0.000 & 0.000 & 0.000 & 0.000 & 0.000 & 0.218 & & \\
\hline \multirow[t]{2}{*}{ LNTDE } & 0.636 & 0.104 & 0.086 & 0.541 & 0.622 & -0.554 & 0.070 & 0.643 & -0.206 & 0.6972 & 1 \\
\hline & 0.000 & 0.072 & 0.137 & 0.000 & 0.000 & 0.000 & 0.229 & 0.000 & 0.000 & 0.000 & \\
\hline
\end{tabular}




\section{Appendix C. Descriptive statistics of variables}

The following is a summary of the descriptive statistics of the variables analyzed.

\begin{tabular}{c|ccccc} 
Variable & Obs & Mean & Std. Dev. & Min & Max \\
\hline LNNBF & 209 & 0.2818863 & 1.55042 & -3.618687 & 3.320515 \\
LNREER & 300 & 4.588745 & 0.1147184 & 4.160587 & 4.913376 \\
LNGCE & 299 & -1.959631 & 0.3061049 & -2.685486 & -1.450081 \\
LNDCPS & 297 & -0.7565576 & 0.6505255 & -2.288395 & 0.7041503 \\
LNGDPP & 300 & 9.129745 & 0.7442018 & 7.505405 & 10.88914 \\
\hline LNUE & 246 & -2.517127 & 0.5627875 & -4.422849 & -1.164752 \\
LNSPRB & 270 & 2.054048 & 0.4024881 & 1.098612 & 2.944439 \\
LNCI & 300 & 1.399485 & 0.3391012 & 0.6418539 & 2.24071 \\
LNNEER & 300 & 4.59344 & 0.1109252 & 4.223138 & 5.045853 \\
LNTDE & 299 & 4.441335 & 0.6627107 & 3.096405 & 6.100424 \\
\hline LNFDI & 294 & -3.421338 & 1.033756 & -7.475258 & -0.6559314
\end{tabular}

\section{Appendix D. Unit root tests}

In the following table, the results of the unit root tests applied to each variable using the Phillips-Perron method are reported. The tests do not present arguments in favor of the presence of unit roots, making it possible to point out that the series analyzed prove to be stationary.

\begin{tabular}{c|cccccccc}
\multirow{2}{*}{ Variables } & Inverse chi-square $(\mathbf{P})$ & \multicolumn{2}{c}{ Inverse normal $(\mathbf{Z})$} & \multicolumn{2}{c}{ Inverse logit $\left(\mathbf{L}^{*}\right)$} & \multicolumn{2}{c}{ Modified inverse chi-square $(\mathbf{P m})$} \\
\cline { 2 - 8 } & Statitistical & P-value & Statitistical & P-value & Statitistical & $\begin{array}{c}\text { P- } \\
\text { value }\end{array}$ & Statitistical & P-value \\
\hline LNNBF & 375.548 & 0.000 & -9.143 & 0.000 & -18.900 & 0.000 & 28.806 & 0.000 \\
LNREER & 265.639 & 0.000 & -4.714 & 0.000 & -9.215 & 0.000 & 18.772 & 0.000 \\
LNGCE & 189.156 & 0.000 & -1.857 & 0.032 & -5.085 & 0.000 & 11.790 & 0.000 \\
LNDCPS & 210.169 & 0.000 & -1.772 & 0.038 & -7.419 & 0.000 & 13.709 & 0.000 \\
LNGDPP & 115.073 & 0.000 & -1.764 & 0.039 & -2.065 & 0.020 & 5.028 & 0.000 \\
LNUE & 79.448 & 0.000 & 1.406 & 0.920 & 0.536 & 0.704 & 1.991 & 0.023 \\
LNSPRB & 120.295 & 0.000 & -0.563 & 0.287 & -3.431 & 0.000 & 5.504 & 0.000 \\
LNCI & 122.428 & 0.000 & 0.846 & 0.081 & -0.201 & 0.421 & 5.699 & 0.000 \\
LNNEER & 326.17 & 0.000 & -7.544 & 0.000 & -13.61 & 0.000 & 24.298 & 0.000 \\
LNFDI & 291.292 & 0.000 & -5.66 & 0.000 & -11.165 & 0.000 & 21.114 & 0.000 \\
LNTDE & 115.545 & 0.000 & -1.519 & 0.064 & -2.433 & 0.008 & 5.071 & 0.000 \\
\hline
\end{tabular}




\section{References:}

Aidis, R, S Estrin and TM Mickiewicz (2012). Size Matters: Entrepreneurial entry and Government. Journal of Small Business Economics, 39(1), 119-139.

Ayyagari, M and R Kosová (2010). Does FDI Facilitate Domestic Entry? Evidence from the Czech Republic. Review of International Economics, 18(1), 14-29.

Bahmani-Oskooee, M (1998). Are devaluations contractionary in LDCs? Journal of Economic Development, 23(1), 131-144.

Balassa, B (1964). The Purchasing Power Parity Doctrine: A Reappraisal. Journal of Political Economy, 72, 584-596.

Barbosa, N and V Eiriz (2007). The role of inward foreign direct investment on entrepreneurship. International Entrepreneurship and Management Journal, 5(3), 319-339.

Barrios, S, H Görg and E Strobl (2005). Foreign direct investment, competition and industrial development in the host country. European Economic Review, 49, 1761-1784.

Beck, N and JN Katz (1995). What to do (and not to do) with time-series cross section data. American Political Science Review, 89(3), 634-647.

Bhalla, SS (2007). Economic development and the role of currency undervaluation. The Cato Journal, 28(2), 313-340.

Bhalla, SS (2012). Devaluing to Prosperity: Misaligned Currencies and Their Growth Consequences. Peterson Institute for International Economics, Washington, DC.

Black, SE and PE Strahan (2002). Entrepreneurship and Bank Credit Availability. The Journal of Finance. 57(6), 2807- 2832.

Breusch, TS and AR Pagan (1980). The Lagrange Multiplier Test and its Applications to Model Specification in Econometrics. The Review of Economic Studies, 47(1), 239-253.

Bruhn, M (2011). License to sell: The effect of business registration reform on entrepreneurial activity in Mexico. The Review of Economics and Statistics, 93(1), 382-386.

Bruton, GD, Ahlstrom and HL Li (2010). Institutional theory and entrepreneurship: Where are we now and where do we need to move in the future? Entrepreneurship Theory and Practice, 34(3), 421440 .

Burke, A. et al., (2007). The impact of foreign direct investment on new firm survival in the UK: evidence for static versus dynamic industries. Journal of Small Business Economics, 31(4), 395407.

Clercq, DD, J Hessels, and A Stel (2008). Knowledge spillovers and new ventures' orientation. Journal Small Business Economics, 31(3), 283-303.

Choi, YR and PH Phan (2006). The Influences of Economic and Technology Policy on the Dynamics of New Firm Formation. Journal of Small Business Economics, 26, 493-503.

Daboh, L (2010). Real Exchange Rate Misalignment in the West African Monetary Zone. Journal of Monetary and Economic Integrated, 10(2), 1-116.

Darvas, Z (2012). Real Effective Exchange Rates for 178 Countries: A New Database. Bruegel Working Paper.

Darvas, Z (2013). Monetary transmission in three central European economies: evidence from timevarying coefficient vector autoregressions. Empirica, 40(2), 363-390. 
Dreher, A and M Gassebner (2013). Greasing the wheels? The impact of regulations and corruption on firm entry. Public Choice, 155(3-4), 413-432.

Drine, I and C Rault (2003). On the long-run determinants of the real exchange rate for developing countries: Evidence from Africa, Latin America and Asia. William Davidson. Working Paper, Number 571.

Edwards, S (1986). Are Devaluations Contractionary? The Review of Economics and Statistics, 68 (3), 501-508.

Edwards, S (1988). Real and monetary determinants of real exchange behavior: Theory and evidence from developing countries. Journal of Development Economics, 29(3), 311-341.

Edwards, S (1989). Exchange Rate Misalignment in Developing Countries. The World Bank Reserch Observer, 4(1), 3-21.

Eichengreen, B (2013). Currency War or International Policy Coordination? Journal of Policy Modeling, 35(3), 425-433.

Eichengreen, B and S Jeffrey (1985). Exchange Rates and Economic Recovery in the 1930s. Journal of Economy History, 49, 924-946.

Eichengreen, B and S Jeffrey (1986). Competitive Devaluation and the Great Depression: A Theoretical Reassessment. Economics Letters, 22, 67-72.

Elbadawi, IA (1994). Estimating Long-Run Equilibrium Real Exchange Rate. In John Williamson, Ed. 1994. Estimating Equilibrium Exchange Rates. Washington, D.C. Institute for International Economics, 93-131.

Evans, DS and B Jovanovic (1989). An Estimated Model of Entrepreneurial Choice under Liquidity Constraints. Chicago Journal, 97(4), 808-827.

Friedland, R and J Sanders (1985). The Public Economy and Economic Growth in Western Market Economies. American Sociological Review, 50(4), 421-437.

Froot, KA and JC Stein (1991). Exchange Rate and Direct Investment: An Imperfect Capital Markets Approach. The Quartely Journal Economics, 106(4), 1191-1217.

Gala, P (2007). Real exchange rate levels and economic development: theoretical analysis and econometric evidence. Cambridge Journal of Economics, 32(2), 273-288.

González, FM (2005). Insurance Property and Technological Backwardness. The Economic Journal, 115(505), 703-721.

Gwartney, JD, RG Holcombe and RA Lawson (2004). Economic Freedom, Institutional Quality and Cross-Country Differences In Income And Growth. The Cato Journal, 24(3), 205-233.

Hausman, JA (1978). Specification Test in Econometrics. Econometrica, 46(6), 1251-1271.

He, Q (2010). Expanding Varieties in the Nontraded Goods Sector and the Real Exchange Rate Depreciation. Journal of International and Global Economic Studies, 3(2), 19-38.

Herrera-Echeverri, H, J Haar, and J Benavides (2014). Foreign direct investment, institutional quality, economic freedom and entrepreneurship in emerging markets. Journal of Business Research, 67, 1921-1932.

Hoechle, D (2007). Robust Standard Errors for Panel Regressions whit Cross-Sectional Dependence. The Stata Journal, 7(3), 281-312.

Hussain, S (2011). Dutch Disease Investigated: Empirical Evidence from Selected South-East Asian Economies. Journal of Economic Cooperation and Developmental, 32(4), 51-74.

Johnson, S, D Kaufmann and A Shleifer (1997). Politics and Entrepreneurship in Transition Economies. William Davidson. Working Paper Number 57.

Joyce, JP and L Kamas, (2010). Real and nominal determinants of real exchange rates in Latin America: Short-run dynamics and long-run equilibrium. The Journal of Development Studies, 39(6), 155182. 
Karadeloglou, P, G Chobanov, A Delakorda, W Milo and P Wdowinski (2001). The Exchange Rate, Prices and the Supply Response under Transition: A Simulation Study in Exchange Rate Policies, Prices and the Supply Response. Eds by C. Papazoglou. E.J. Pentecost. Chapter 6. Palgrave. Basingstoke. 78-88.

Kelley, DJ, S Singer and M Herrington (2012). The global entrepreneurship monitor. 2011 Global Report, 7.

Kim, BY and I Korhonen (2005). Equilibrium exchange rates in transition countries: Evidence from dynamic heterogeneous panel models. Economic Systems, 29(2), 144-162.

Klapper, L., et al. (2007). Entrepreneurship and Firm Formation across Countries. World Bank. Policy Research Working Paper, 4313.

Klapper, L and I Love (2010). The Impact of the Financial Crisis on New Business Registration. World Bank. Policy Research Working Paper, 5444.

Koveos, P, P Yourougou and BA Adu (2011). Entrepreneurship in Africa. Journal of Developmental Entrepreneurship, 16(1), 1-7.

Kosteletou, N and P Liargovas (2000). Foreign Direct Investment and Real Exchange Rate Interlinkages. Open Economic Review, 11, 135-148.

Krugman, P and L Taylor (1978). Contractionary Effects of Devaluation. Journal of International Economics, 8 (3), 445-456.

Levy-Yeyati, E and F Sturzenegger (2007). Fear of Appreciation. World Bank. Policy Research Working Paper, 4387.

Markusen, J and A Venables (1999). Foreign direct investment as a catalyst for industrial development. European Economic Review, 43 (2), 335-356.

Mbaye, S (2012). Real Exchange Rate Undervaluation and Growth: is there a Total Factor Productivity Channel? Working Paper E 2012.11. Centre D'Etudes Et De Recherches Sur Le Dèv. International.

Misra, K and E Memili and DHB Welsh (2012). The Determinants of Venture Creation Time: A CrossCountry Perspective. International Entrepreneurship and Management Journal.

Montiel, PJ (1999). Determinants of the Long-Run Equilibrium Real Exchange Rate: An Analytical Model. In Lawrence Hinkle and Peter J. Montiel. Ed. 1999. Exchange Rate Misalignment: Concepts and Measurement for Developing Countries. 264-290. A World Bank. Research Publication, Oxford University Press.

Munemo, J (2012). Entrepreneurship in developing countries: is Africa different? Journal Developmental Entrepreneurship, 17(1).

Quéré, AB, M Coupet and T Mayer (2005). Institutional Determinants of Foreign Direct Investment. CEPII, Working Paper No 05.

Rehman, H, AA Jaffri and I Ahmed (2010). Impact of Foreign Direct Investment (FDI) Inflows on Equilibrium Real Exchange Rate of Pakistan. A Research Journal of South Asian Studies, 25(1), 125-141.

Reynolds, PD, A Zacharakis and WD Bygrave (1999). Global Entrepreneurship Monitor: 1999 Executive Report. Kauffman Center for Entrepreneurial Leadership.

Reynolds, PD. et al., (2000). Global Entrepreneurship Monitor: 2000 Executive Report, Kauffman. Center for Entrepreneurial Leadership.

Rodrik, D (2008). The Real Exchange Rate and Economic Growth. Brookings Paper on Economic Activity, 2, 365-412.

Robb, A and D Robinson (2012). The capital structure decisions of new firms. Review of Financial Studies in preparation, 12-17. 
Samuelson, PA (1964). Theoretical notes on trade problems. Review of Economics and Statistics, 46(2), 145-54.

Scholz, JT (1986). Regulatory Enforcement in a Federalist System. The American Political Science Review, 80(4), 1249-1270.

Schwab, K., 2011. Global Competitiveness Report 2011-2012. World Economic Forum.

Schwab, K., 2012. Global Competitiveness Report 2012-2013. World Economic Forum.

Spencer, JW and C Gómez (2004). The relationship among national institutional structures, economic factors, and domestic entrepreneurial activity: a multicountry study. Journal of Business Research, 57(10), 1098-1107.

Startz, R (1989). Monopolistic Competition as a Foundation for Keynesian Macroeconomic Models. The Quartely Journal of Economics, 104(4), 737-752.

Sutaria, V and DA Hicks (2004). New firm formation: Dynamics and determinants. The Annals of Regional Science, 38(2), 241-262.

Takii, K (2008). Fiscal policy and entrepreneurship. Journal of Economic Behavoral \& Organization, 65(3-4), 592-608.

Wahid, ANM and M Shahbaz (2009). Does Nominal Devaluation Precede Real Devaluation? The Case of Philippines. Transition Study Review, 16(1), 47-61.

Wei, S (2000). How Taxing is Corruption on International Investors? The Review of Economics and Statistics, 82(1), 1-11.

$\mathrm{Wu}, \mathrm{S}$ and $\mathrm{X}$ Liang (2012). An examination of the relationship between corruption and total entrepreneurial activity. World Review of Entrepreneurship, Management and Sustainable Development, 8(4), 478-489.

$\mathrm{Xu}, \mathrm{D}$ and SJ Chang (2008). Spillovers and competition among foreign and local firms in China. Strategic Management Journal, 29(5), 495-518.

Yao, S.J and KL Wei (2007). Economic growth in the presences of FDI: The perspective of newly industrializing economies. Journal of Comparative Economics, 35, 211-234.

Zhang, KH (2006). Foreign direct investment and economic growth in China: A panel data study for 1992-2004. Conference of 'WTO, China and Asian Economies'. Beijing, China. 
Table 1. List of countries that make up the study sample.

\begin{tabular}{|c|c|c|c|}
\hline Country & Region & Country & Region \\
\hline Argentina $^{a}$ & Latin America & Malaysia $^{\text {a }}$ & Asia \\
\hline Brazil $^{\text {a }}$ & Latin America & Mauritius $^{\text {a }}$ & Africa \\
\hline Bulgaria $^{a}$ & Europe & Mexico $^{a}$ & Latin America \\
\hline Chile $^{\text {a }}$ & Latin America & Morocco $^{\text {a }}$ & Africa \\
\hline Colombia $^{\text {a }}$ & Latin America & Pakistan $^{a}$ & Asia \\
\hline Czech Republic $^{\text {a }}$ & Europe & Peru $^{a}$ & Latin America \\
\hline Egypt $^{\text {a }}$ & Africa & Philippines ${ }^{\text {a }}$ & Asia \\
\hline Estonia $^{\text {a }}$ & Europe & Poland $^{\text {a }}$ & Europe \\
\hline Hong Kong ${ }^{b}$ & Asia & Romania $^{\text {a }}$ & Europe \\
\hline Hungary ${ }^{a}$ & Europe & Singapore $^{\mathrm{b}}$ & Asia \\
\hline India $^{a}$ & Asia & Slovakia $^{a}$ & Europe \\
\hline Indonesia $^{\text {a }}$ & Asia & South Africa ${ }^{a}$ & Africa \\
\hline Jordan $^{\text {a }}$ & Asia & Sri Lanka ${ }^{a}$ & Asia \\
\hline Latvia $^{\text {a }}$ & Europe & Thailand ${ }^{a}$ & Asia \\
\hline Lithuania $^{\text {a }}$ & Europe & Turkey ${ }^{\text {a }}$ & Europe \\
\hline
\end{tabular}

${ }^{a}$ Emerging countries according to the Dow Jones and The Economist.

${ }^{b}$ Emerging countries according to The Economist. 
Table 2

\begin{tabular}{|c|c|c|c|c|}
\hline \multicolumn{5}{|c|}{ Business formation in emerging countries } \\
\hline \multirow{3}{*}{$\begin{array}{l}\text { Independent } \\
\text { variables }\end{array}$} & \multicolumn{4}{|c|}{ Dependent variable } \\
\hline & \multicolumn{4}{|c|}{ New business formation } \\
\hline & \multicolumn{2}{|c|}{ (1) } & \multicolumn{2}{|c|}{ (2) } \\
\hline LNREER $_{t-2}$ & \multicolumn{2}{|c|}{$0.388(0.050)^{* *}$} & \multicolumn{2}{|c|}{ - } \\
\hline LNREER $_{t-3}$ & \multicolumn{2}{|c|}{-} & \multicolumn{2}{|c|}{$0.241(0.269)$} \\
\hline$L N G C E_{t-1}$ & \multicolumn{2}{|c|}{$-1.308(0.000) * * *$} & \multicolumn{2}{|c|}{$-1.298(0.000) * * *$} \\
\hline$L N D C P S_{t-1}$ & \multicolumn{2}{|c|}{$0.278(0.000) * * *$} & \multicolumn{2}{|c|}{$0.285(0.000) * * *$} \\
\hline$L N G D P P_{t-2}$ & \multicolumn{2}{|c|}{$0.611(0.000) * * *$} & \multicolumn{2}{|c|}{$0.572(0.000) * * *$} \\
\hline$L N U E_{t-1}$ & \multicolumn{2}{|c|}{$0.256(0.000) * * *$} & \multicolumn{2}{|c|}{$0.245(0.000) * * *$} \\
\hline$L N S P R B_{t-1}$ & \multicolumn{2}{|c|}{$-0.430(0.000) * * *$} & \multicolumn{2}{|c|}{$-0.507(0.000) * * *$} \\
\hline$L N C I_{t-1}$ & \multicolumn{2}{|c|}{$0.906(0.000) * * *$} & \multicolumn{2}{|c|}{$0.966(0.000) * * *$} \\
\hline Constant & \multicolumn{2}{|c|}{$-9.549(0.000) * * *$} & \multicolumn{2}{|c|}{$-8.464(0.000) * * *$} \\
\hline Temporal dummies & \multicolumn{2}{|c|}{ Yes } & \multicolumn{2}{|c|}{ Yes } \\
\hline Dummies per countries & \multicolumn{2}{|c|}{ Yes } & \multicolumn{2}{|c|}{ Yes } \\
\hline$\overline{R^{2}}$ & \multicolumn{2}{|c|}{0.954} & \multicolumn{2}{|c|}{0.956} \\
\hline Observations & \multicolumn{2}{|c|}{190} & \multicolumn{2}{|c|}{165} \\
\hline Number of countries & \multicolumn{2}{|c|}{30} & \multicolumn{2}{|c|}{30} \\
\hline Tests & Stat. & P-value & Stat. & P-value \\
\hline Wald Chi(26) & 5317.50 & 0.000 & 4860.09 & 0.000 \\
\hline Hausman & 35.35 & 0.000 & 25.93 & 0.001 \\
\hline Breusch-Pagan & 351.09 & 0.000 & 264.82 & 0.000 \\
\hline Modified Wald het. & 2160.46 & 0.000 & 56072.14 & 0.000 \\
\hline Serial Correlation LM & 18.012 & 0.000 & 18.012 & 0.000 \\
\hline Model & PCS & (ar1) & PCS & ar1) \\
\hline
\end{tabular}

Depended variable $i$ at year $t$ is the number of firms registered per 1,000 economically active population. Independent variables are: Natural log of annual REER in $\mathrm{t}=2\left(\operatorname{LNREER}_{t-2}\right)$, natural $\log$ of the government expenditures as a percentage of GDP in $\mathrm{t}=1\left(\mathrm{LNGCE}_{t-1}\right)$, natural $\log$ of the availability of credit for the private sector as a percentage of GDP in $\mathrm{t}=1\left(\operatorname{LNDCPS}_{t-1}\right)$, natural $\log$ of the growth of GDP per capita movement in $\mathrm{t}=2\left(L N G D P P_{t-2}\right)$, natural $\log$ of the unemployment rate in $\mathrm{t}=1\left(L N U E_{t-1}\right)$, natural $\log$ of the excess of procedures required for registering a business in $\mathrm{t}=1\left(L N S P R B_{t-1}\right)$ and natural $\log$ of the corruption index in $\mathrm{t}=1\left(L N C I_{t-1}\right)$. The coefficient of the regression are based on Panel-Corrected Standard Errors (PCSE). The statistical T is specified in parentheses. ${ }^{* * *}$ and ${ }^{* *}$ which means significance at $1 \%$ and $5 \%$ respectively. 
Table 3

\begin{tabular}{|c|c|c|}
\hline \multicolumn{3}{|c|}{ Devaluation in emerging countries } \\
\hline \multirow{2}{*}{$\begin{array}{l}\text { Independent } \\
\text { variables }\end{array}$} & \multicolumn{2}{|c|}{ Dependent variable } \\
\hline & \multicolumn{2}{|c|}{ Real effective exchange rate } \\
\hline & \multicolumn{2}{|c|}{ (3) } \\
\hline$L N G C E_{t-1}$ & \multicolumn{2}{|c|}{$-0.069(0.009)^{* * * *}$} \\
\hline$L N D C P S_{t-1}$ & \multicolumn{2}{|c|}{$0.053(0.000)^{* * * *}$} \\
\hline$L N G D P P_{t-2}$ & \multicolumn{2}{|c|}{$0.139(0.000)^{* * * *}$} \\
\hline LNNEER & \multicolumn{2}{|c|}{$0.646(0.000)^{* * *}$} \\
\hline$L N T D E_{t-I}$ & \multicolumn{2}{|c|}{$-0.068(0.000)^{* * *}$} \\
\hline$L N F D I_{t-1}$ & \multicolumn{2}{|c|}{$0.017(0.003)^{* * *}$} \\
\hline Constant & \multicolumn{2}{|c|}{$0.366(0.152)$} \\
\hline Temporal dummies & \multicolumn{2}{|c|}{ Yes } \\
\hline Dummies per countries & \multicolumn{2}{|c|}{ Yes } \\
\hline$R^{2}$ & \multicolumn{2}{|c|}{0.994} \\
\hline Observations & \multicolumn{2}{|c|}{233} \\
\hline Number of countries & \multicolumn{2}{|c|}{30} \\
\hline Tests & Stat. & P-value \\
\hline Wald Chi(18) & 520.89 & 0.000 \\
\hline Hausman & 143.55 & 0.000 \\
\hline Breusch-Pagan & 0.74 & 0.389 \\
\hline Modified Wald het. & 4386.52 & 0.000 \\
\hline Serial Correlation LM & 466.221 & 0.000 \\
\hline Model & \multicolumn{2}{|c|}{ PSCE c(ar1) } \\
\hline
\end{tabular}

Depended variable $i$ at year $t$ is the number of firms registered per 1,000 economically active population. Independent variables are: Natural log of the government expenditures as a percentage of GDP $\left(L N G C E_{t-1}\right)$, natural $\log$ of the availability of credit for the private sector as a percentage of GDP $\left(L N D C P S_{t-1}\right)$, natural log of the growth of GDP per capita movement $\left(L N G D P P_{t-2}\right)$, natural log of the effect of nominal exchange rate $\left(L N N E E R_{t}\right)$, natural log of the sum of exports and imports of goods and services as a percentage of GDP $\left(L N T D E_{t-1}\right)$ and natural log of the net foreign direct investment as a percentage of GDP $\left(L N F D I_{\mathrm{t}-}\right.$ $\left.{ }_{1}\right)$. The coefficient of the regression are based on PanelCorrected Standard Errors (PCSE). The statistical $\mathrm{T}$ is specified in parentheses. ${ }^{* * *}$ means significance at $1 \%$. 
Table 4

\begin{tabular}{|c|c|c|c|c|c|c|c|c|}
\hline \multicolumn{9}{|c|}{ Devaluation, competitiveness and business formation in emerging countries } \\
\hline \multirow{3}{*}{$\begin{array}{c}\text { Independent } \\
\text { variables }\end{array}$} & \multicolumn{8}{|c|}{ Dependent variable } \\
\hline & \multicolumn{8}{|c|}{ New business formation } \\
\hline & \multicolumn{2}{|c|}{ (4) } & \multicolumn{2}{|c|}{$(5)$} & \multicolumn{2}{|c|}{ (6) } & \multicolumn{2}{|c|}{ (7) } \\
\hline$L N R E E *_{t-2}$ & \multicolumn{2}{|c|}{$0.539(0.020)^{* *}$} & \multicolumn{2}{|c|}{$0.454(0.061)^{*}$} & \multicolumn{2}{|c|}{$0.468(0.067)^{*}$} & \multicolumn{2}{|c|}{$0.273(0.296)$} \\
\hline$L N G C E_{t-1}$ & \multicolumn{2}{|c|}{$-1.366(0.000)^{* * *}$} & \multicolumn{2}{|c|}{$-1.351(0.00)^{* * *}$} & \multicolumn{2}{|c|}{$-1.367(0.000)^{* * * *}$} & \multicolumn{2}{|c|}{$-1.354(0.000)^{* * * *}$} \\
\hline$L N D C P S_{t-1}$ & \multicolumn{2}{|c|}{$0.296(0.000) * * *$} & \multicolumn{2}{|c|}{-} & \multicolumn{2}{|c|}{$0.468(0.000)^{* * *}$} & \multicolumn{2}{|c|}{-} \\
\hline$L N D C P S^{<=Q 2}{ }_{t-1}$ & \multicolumn{2}{|c|}{-} & \multicolumn{2}{|c|}{$0.191(0.000)^{* * *}$} & \multicolumn{2}{|c|}{-} & \multicolumn{2}{|c|}{$0.364(0.000)^{* * *}$} \\
\hline$L N G D P P_{t-2}$ & \multicolumn{2}{|c|}{$0.630(0.000) * * *$} & \multicolumn{2}{|c|}{$0.596(0.000)^{* * *}$} & \multicolumn{2}{|c|}{$0.877(0.000)^{* * *}$} & \multicolumn{2}{|c|}{$0.861(0.000)^{* * *}$} \\
\hline$L N U E_{t-1}$ & \multicolumn{2}{|c|}{$0.245(0.000) * * *$} & \multicolumn{2}{|c|}{$0.255(0.000)^{* * *}$} & \multicolumn{2}{|c|}{$0.220(0.000)^{* * *}$} & \multicolumn{2}{|c|}{$0.243(0.000)^{* * *}$} \\
\hline$L N S P R B_{t-1}$ & $-0.491(0$ & $.000)^{* * *}$ & $-0.568(0$ & $000)^{* * *}$ & $-0.557(0$ & $000)^{* * * *}$ & $-0.674(($ & $000)^{* * *}$ \\
\hline$L N C I_{t-1}$ & $1.010(0$ & $000) * * *$ & $1.132(0$ & $000)^{* * *}$ & - & & & \\
\hline$L N C I^{<}=Q{ }_{t-1}$ & . & & & & $-0.214(0$. & $002)^{* * *}$ & $-0.243(($ & $001)^{* * *}$ \\
\hline Constant & $-9.836(0$ & $.000)^{* * *}$ & $-9.286(0$ & $000)^{* * *}$ & $-10.082(0$ & $000)^{* * *}$ & $-9.038(($ & $000)^{* * *}$ \\
\hline Temporal dummies & $\mathrm{Y}$ & & & & $\mathrm{Ye}$ & & & \\
\hline $\begin{array}{l}\text { Dummies } \\
\text { countries }\end{array}$ & $Y$ & & & & $\mathrm{Ye}$ & & & es \\
\hline$\overline{R^{2}}$ & 0.9 & & & & 0.9 & & & 47 \\
\hline Observations & 16 & & & & 16 & & & 65 \\
\hline Number of countries & 3 & & & & 30 & & & 0 \\
\hline Tests & Stat. & P-value & Stat. & P-value & Stat. & P-value & Stat. & P-value \\
\hline Wald Chi(26) & 5238.16 & 0.000 & 4352.43 & 0.000 & 4580.59 & 0.000 & 3925.07 & 0.000 \\
\hline Hausman & 32.38 & 0.000 & 33.30 & 0.000 & 24.41 & 0.002 & 29.47 & 0.000 \\
\hline Breusch-Pagan & 269.35 & 0.000 & 269.25 & 0.000 & 268.75 & 0.000 & 268.84 & 0.000 \\
\hline Modified Wald het. & 4980.05 & 0.000 & 6721.93 & 0.000 & 4720.40 & 0.000 & 6758.41 & 0.000 \\
\hline $\begin{array}{l}\text { Serial Correlation } \\
\text { LM }\end{array}$ & 18.288 & 0.000 & 18.861 & 0.000 & 18.225 & 0.000 & 18.848 & 0.000 \\
\hline Model & PCSE & $\mathrm{c}(\operatorname{ar} 1)$ & PCSE & $\mathrm{c}(\operatorname{ar} 1)$ & PCSE & $(\operatorname{ar} 1)$ & PCSE & $\mathrm{c}(\operatorname{ar} 1)$ \\
\hline
\end{tabular}

Depended variable $i$ at year $t$ is the number of firms registered per 1,000 economically active population. Independent variables are: Natural $\log$ of the residuals that result from extracting the effect of the variables causing both NBF and REER $\left(L N R E E R *_{t-2}\right)$, natural log of the government expenditures as a percentage of GDP $\left(L N G C E_{t-1}\right)$, natural $\log$ of the availability of credit for the private sector as a percentage of GDP $\left(L N D C P S_{t-1}\right)$, natural log of the quartile one of domestic credit supply to the private sector as a percentage of GDP $\left(L N D C P S^{<=Q 2}{ }_{t-1}\right)$, natural $\log$ of the growth of GDP per capita movement $\left(L N G D P P_{t-2}\right)$, natural log of the unemployment rate $\left(L N U E_{t-1}\right)$, natural log of the excess of procedures required for registering a business $\left(L N S P R B_{t-1}\right)$, natural $\log$ of the corruption index $\left(L N C I_{t-l}\right)$ and natural $\log$ of the quartile two of domestic credit supply to the private sector as a percentage of GDP $\left(L N C I^{<=Q 2}{ }_{t-}\right.$ 1). The coefficient of the regression are based on Panel-Corrected Standard Errors (PCSE). The statistical $\mathrm{T}$ is specified in parentheses. ${ }^{* * *},{ }^{* *}$ and ${ }^{*}$ which means significance at $1 \%, 5 \%$ and $10 \%$ respectively. 